that the extent of inhibition was related to substrate concentration. With the exception of the lowest $\mathrm{pH}$ (5.2), where liberation of PUFA was more inhibited, liberation of all fatty acids from SO was roughly inhibited to a same extent by lowering $\mathrm{pH}$. Overall hydrogenation of liberated fatty acids was not affected by $\mathrm{pH}$. Linolenic and linoleic acid were always almost completely hydrogenated, suggesting that hydrogenase action was much less influenced by $\mathrm{pH}$ than lipase activity, whereas, in agreement with literature data, C18:1 accumulation was observed.

* Research financed by IWONL, Brussels

\section{Ruminal and hindgut digesta kinetic parameters in sheep estimated from fae- cal-marker excretion and slaughter trials.} A de Vega, J Gasa *, C Castrillo, JA Guada (Dpto de Producción Animal y Ciencia de los Alimentos, Miguel Servet, 177, 50013 Zaragoza; * present address: Dpt de Produccio Animal, Universitat Autónoma de Barcelona, Bellaterra 18193, Barcelona, Spain)

Faecal-marker excretion curves after a pulse dose of reference substances have been used to estimate digesta kinetic parameters through the different mixing compartments of the gut, although there is a lack of agreement on their interpretation. In order to better understand this subject, an experiment was carried out on 4 pairs of twin Rasa Aragonesa ewe lambs fed a chopped (C; $44.8 \%$ digestible organic matter (DOM)) or pelleted $(\mathrm{P} ; 40.9 \% \mathrm{DOM})$ lucerne hay at $90 \%$ of their voluntary intake $(65$ and $88 \mathrm{~g} \mathrm{DM} / \mathrm{kg}$ body weight 0.75 ) and offered in 12 daily equal meals. Animals were single dosed $10 \mathrm{~g}$ of Yb-labelled forage and $0.5 \mathrm{~g}$ of Co-EDTA, and 19 faecal samples were taken for up to $144 \mathrm{~h}$. Slow $\left(K_{1}\right)$ and fast $\left(K_{2}\right)$ fractional outflow rates were obtained from the marker concentration curves using the multicompartmental model. After a 2-d resting period and for 5 consecutive days, daily doses of $6 \mathrm{~g}$ of Yb-labelled diets and $0.2 \mathrm{~g}$ Co-EDTA were given by mouth in 12 separate distributions at intervals of $2 \mathrm{~h}$. Pairs of animals were slaughtered every $2 \mathrm{~h}$ on the 6th day, and fractional outflow rates of both markers from reticulo-rumen $(K r)$ and hindgut $\left(K_{\mathrm{HG}}\right)$ calculated for each animal. Calculations were made using the hourly infusion of markers and their actual amounts in the compartments. The latter were estimated from digesta marker concentrations and the total amount of material present in the pools considered. Mean $K_{1}$ values were $0.056(\operatorname{diet} C)$ and 0.077 (diet P) $\mathrm{h}^{-1}$ for Co-EDTA $(P<0.001)$ and $0.049(\mathrm{C})$ and $0.057(\mathrm{P}) \mathrm{h}^{-1}$ for $\mathrm{Yb}$-labelled diets $(P>0.05) . K_{r}$ value were $0.072(C)$ and 0.154 (P) $\mathrm{h}^{-1}$ for Co-EDTA $(P<0.01)$ and $0.040(\mathrm{C})$ and $0.063(\mathrm{P}) \mathrm{h}^{-1}$ for $\mathrm{Yb}$-labelled particles $(P<$ 0.05 ). Average $K_{2}$ values were $0.445(C)$ and $0.627(\mathrm{P}) \mathrm{h}^{-1}$ for Co-EDTA and 0.309 (C) and $0.405(\mathrm{P}) \mathrm{h}^{-1}$ for $\mathrm{Yb}$, whereas $K_{\mathrm{HG}}$ values were always lower than $K_{2}$ and nearly constant $(0.138 \pm$ 0.012 ), independently of the marker or the kind of diet considered. In conclusion, $K_{1}$ did not reflect the differences in $\mathrm{Yb}$ fractional outflow rates from the rumen between $C$ and $P$, while in the case of Co-EDTA differences of $K_{\mathrm{r}}$ due to diet were much higher than differences in $K_{1}$. $K_{\mathrm{HG}}$ values were independent of $K_{2}$ with both markers.

\section{Evaluation of faecal indicators to predict voluntary intake of Dichantium sp by cattle in Guadeloupe. M Boval 1, A Xandé 1, JL Peyraud 2, G Aumont 1, O Copry ${ }^{1}$, B Calife ${ }^{1}$ ( ${ }^{1}$ INRA, Station de Zoo- technie, BP 1232, 97185 Pointe-à-Pitre Cedex, Guadeloupe; 2 INRA, Station de Recherches sur la vache laitière, 35990 Saint-Gilles, France)}

The faecal index method has been widely used for estimating digestibility. Single sward regression equations are more accurate than general equations. The objective of this study was to establish a reliable regression between organic matter digestibility (OMD) of Dichantium (dominant in native pastures) and in vitro digestibility (IVD) or faecal indicators: crude protein (CP), neutral detergent fiber (NDF), acid detergent fiber (ADF), and residual nitrogen in $A D F\left(N_{A D F}\right)$. Bands of fresh forage were cut from 20 to $70 \mathrm{~d}$ of regrowth, and chopped. Six creole calves weighing $256 \pm$ $32 \mathrm{~kg}$ were housed in metabolic cages (with ad libitum access to water and a mineral supplement) and were fed 80 percent ad libitum twice daily Measurements were carried out during $50 \mathrm{~d}$ after a 3-week adaptation period. Offered forage, refusals and faeces were weighed every day for each animal. Samples were dried at $80^{\circ} \mathrm{C}$, during $48 \mathrm{~h}$ for forage and $72 \mathrm{~h}$ for faeces. Dry matter 


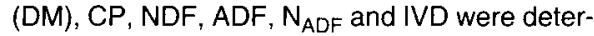
mined by standard procedures (AOAC, 1984) and expressed in \% of organic matter (OM). Faecal output (FO) and OM intake (OMI) were expressed in $\mathrm{kg}$ OM. Mean values were calculated over a 1-week period for each animal. The best regressions were chosen by stepwise procedures with SAS software.

OMI was $4.88 \mathrm{~kg} \mathrm{OM} / \mathrm{d}$ and $\mathrm{OMD}$ ranged from 0.70 to 0.56 . In our conditions $(C P=10.97 \%$; $\mathrm{NDF}=78.7 \% ; \mathrm{ADF}=42.2 \% ; \mathrm{IVD}=0.55)$ the best predictor of OMD was $\mathrm{CP}(\mathrm{OMD}=0.32+$ $0.026 \mathrm{CP} ; \mathrm{RSD}=2.4)$. NDF and ADF were the other only variables to predict $\mathrm{OMD}(\mathrm{RSD}=2.6$ and 3.3, respectively). The other indicators ( $N_{A D F}$ and IVD) were not correlated with OMD. Faecal nitrogen output (FNO, $\mathrm{kg} \mathrm{OM}$ ) was a good predictor of OMI $(\mathrm{OMI}=1.33+17.38 \mathrm{FNO}$; RSD = 0.29 ). The addition of bodyweight $(B W, \mathrm{~kg}$ ) of calves improved RSD (OMI $=1.06+112.4$ FNO $+0.005 \mathrm{BW} ; \mathrm{RSD}=0.25$ ). The prediction error of OMI from FNO is better than the estimation from $\mathrm{OMD}(\mathrm{OMI}=\mathrm{FO} /(1-\mathrm{OMD})$.

Mise au point d'une méthode d'identification de la composition du régime alimentaire des herbivores sur des milieux végétaux complexes. $\mathrm{R}$ Cordesse (UZM ENSA-INRA, 34060 Montpellier, France)

Pour connaître le régime alimentaire d'herbivores sur des parcours arbustifs ou broussailleux, nous avons testé une méthode de tri et d'identification des grosses particules du rumen, images de la composition du dernier repas. L'utilisation de fistules œsophagiennes ou l'observation directe des coups de dents sont d'application trop difficile.

Les prélèvements sont réalisés sur des animaux fistulés du rumen, après la fin du repas principal. Après homogénéisation, dans le rumen, de son contenu, un échantillon ( $150 \mathrm{~g}$ ) est prélevé et lavé sous un courant d'eau. Seules les grosses particules sont retenues sur un jeu de tamis ( 10 à $2,5 \mathrm{~mm}$ ). Les différentes fractions végétales, facilement identifiables sur des critères botaniques, sont séchées et pesées. Une correction prend en compte la matière rapidement solubilisée au contact du jus de rumen et le temps de séjour de la fraction «bois", supérieur à celui des autres composants moins ligneux estimés par ailleurs.

L'efficacité de la méthode a été vérifiée ( 9 répétitions) avec des chèvres ingérant depuis
$10 \mathrm{j}$ un régime de foin de Graminées et de feuilles de chêne kermès dans la proportion de 2/3-1/3. L'ingestion de chaque végétal est connue de façon précise par pesées des quantités distribuées et refusées. Le coefficient de corrélation calculé entre les quantités réellement ingérées et celles mesurées par la méthode est de 0,96.

En garrigue, les choix alimentaires de lamas et de chèvres ont été mesurés, en début et en fin d'exploitation de parcelles expérimentales. La consommation de ligneux et particulièrement de chêne kermès est toujours prédominante chez les chèvres (plus de $90 \%$ ). En revanche, les lamas choisissent de façon prioritaire la strate herbacée ( $83 \%$ en début d'exploitation, $27 \%$ en fin).

Cette méthode de tri et d'identification des particules végétales dans le contenu du rumen nécessite des animaux porteurs de fistule du rumen. Le tri des particules est certes une opération fastidieuse, mais présente les avantages d'être utilisable par tous les temps, sur tous les milieux, avec plusieurs animaux simultanément, et de permettre la répétition des mesures sur le même prélèvement

Prédiction de la digestibilité et des quantités ingérées de fourrages verts à partir de l'analyse en spectrométrie proche infrarouge (SPIR) de fèces de moutons. $\mathrm{V}$ Decruyenaere, $\mathrm{P}$ Lecomte, $\mathrm{P}$ Dardenne (CRA Gembloux, station de Haute-Belgique, 100, rue de Serpont, 6600 Libramont, Belgique)

La prédiction de la digestibilité et des quantités ingérées par l'analyse en SPIR d'échantillons de fèces présente un intérêt certain pour les études de comportement au pâturage ou l'optimisation de l'affouragement à l'étable. Les mesures de digestibilité et de quantités ingérées ont été conduites en continu durant $40 \mathrm{j}$ ( 2 cultures de ray-grass purs) ou $57 \mathrm{j}$ (2 associations fourragères) du premier cycle de végétation de l'herbe. Les fourrages verts étaient offerts quotidiennement en quantités variables (ad libitum, 1,5 $x$ entretien, entretien) à des lots de 2 à 6 moutons. Pour chaque fourrage les digestibilités (dMO, \%) et quantités de matière organique volontairement ingérées selon le poids métabolique (MOvi, $\mathrm{g} / \mathrm{kgP} 0.75$ ) sont établies sur des moyennes

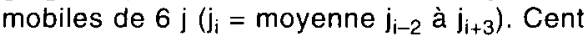
soixante-dix échantillons de fourrages proposés 